\title{
Annular Elastolytic Giant Cell Granuloma Mimicking Pityriasis Versicolor
}

\author{
Chii-Shyan Wang ${ }^{1}$, Hsuan-Hsiang Chen ${ }^{2 *}$ \\ ${ }^{1}$ Department of Dermatology, En Chu Kong Hospital, New Taipei City, Taiwan \\ ${ }^{2}$ Department of Dermatology, National Taiwan University Hospital and National Taiwan University College of Medicine, Taipei, Taiwan
}

Received: June 02, 2016; Accepted: June 04, 2016; Published: June 06, 2016

*Corresponding author: Hsuan-Hsiang Chen, Department of Dermatology, National Taiwan University Hospital, 7, Chung-Shan South Road, Taipei, Taiwan, Tel: +886-2-2356-2141; Fax: +886-2-2393-4177; E-mail: beauty101@gmail.com

\begin{abstract}
Annular Elastolytic Giant Cell Granuloma (AEGCG) is a rare form of granulomatous dermatoses with various clinical manifestations. Herein, apityriasis versicolor-like unusual clinical presentation was presented. The pathological findings and different treatment methods were also briefly reviewed.

Keywords: Annular Elastolytic Giant Cell Granuloma; Pityriasis Versicolor
\end{abstract}

\section{Case Report}

A 43-year-old man went to our clinic with multiple asymptomatic slightly elevated reticulated brownish plaques over chest and neck for 5 years. (Figure 1) He had an indoor occupation with occasional outdoor activities on weekends. The skin lesion started at chest, and these plaques spread gradually and coalesced to form large irregular plaques, mimicking pityriasis versicolor. (Figure 2) He was treated with oral ketoconazole and topical butenafine cream without clinical response 5 years ago, and the skin lesions enlarged gradually. Incision biopsy was performed on the elevated plaque of the neck and the sample was sent for histological examination. Microscopic examination showed granulomatous infiltrates of multinucleated giant cells in the upper and mid dermis without necrobiosis, solar elastosis, or mucin deposition in the upper dermis.(Figure 3) Many multinucleated giant cells are present with phagocytosis of elastic fibers, (Figure 4)which is compatible with annular elastolytic giant cell granuloma. No diabetes or other systemic diseases were found during clinical survey. The patient then received topical clobetasol proprionate foam for 1 month without obvious improvement. He was then lost followup.

\section{Discussion}

Annular Elastolytic Giant Cell Granuloma (AEGCG) is a rare form of granulomatous dermatoses, characterized histologically by phagocytosis of elastic fibers by multinucleated giant cells. AEGCG was isolated in 1979 by Hanke et al. on the basis of five cases seen in females. AEGCG includes the diseases previously

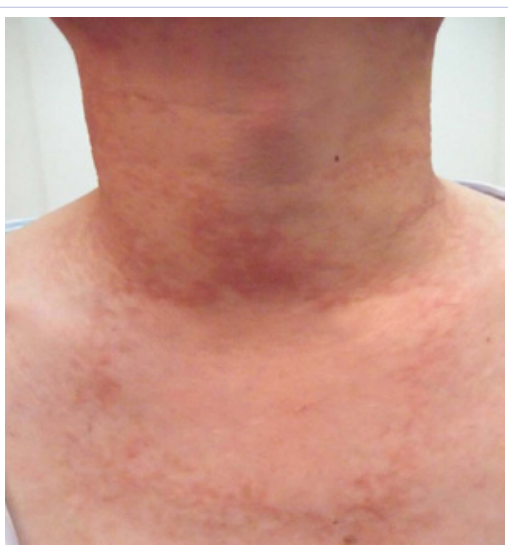

Figure 1: There were asymptomatic slightly elevated reticulated brownish plaques over chest and neck.

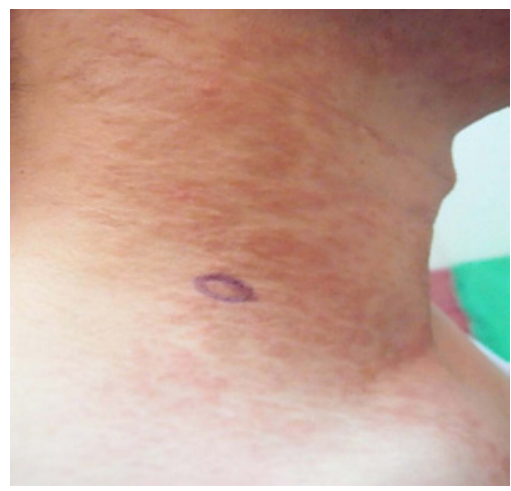

Figure 2: These plaques spread gradually and coalesced to form large irregular plaques, mimicking pityriasis versicolor. The elliptical mark indicated biopsy site.

called as actinic granuloma, atypical facial necrobiosis lipoidica, and Miescher's granuloma [1].

The clinical presentation is variable with erythematous papular lesions, either alone or in groups, with a raised border and a lighter center tending towards atrophy [1-5]. It is an uncommon disease, which usually affects old adults with no 


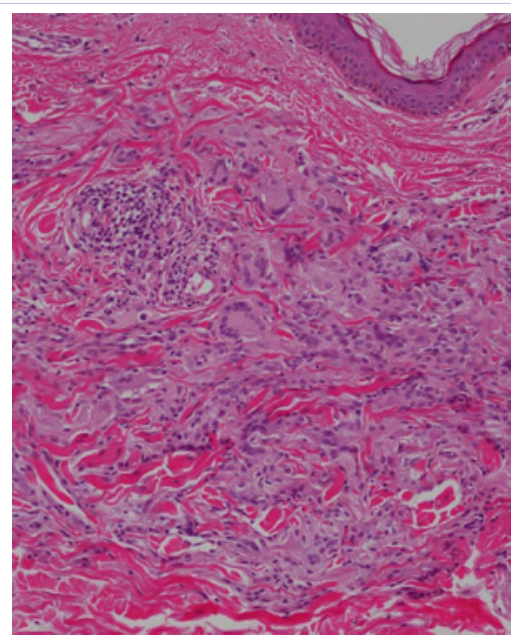

Figure 3: Multinucleated giant cells composing a granulomatous infiltrate occupying the upper and mid dermis. (H \& E, original magnification $\times 100$ ).

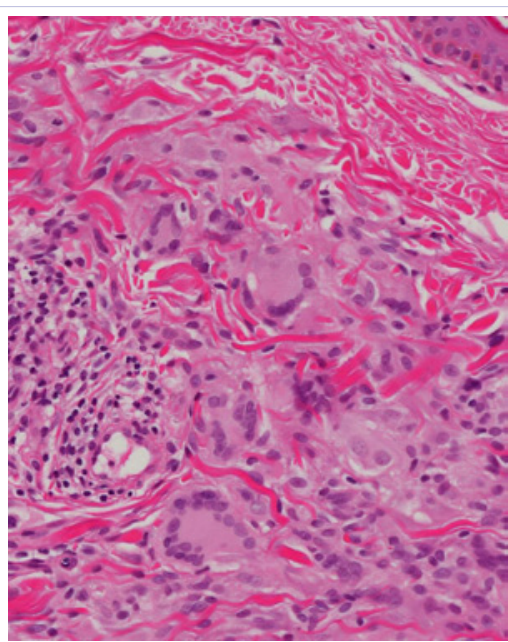

Figure 4: Phagocytosis of elastic fibers by multinucleated giant cells. (H\&E, original magnification $\times 200$ ).

sexual predilection and frequently occurs on the sun-exposed area. However, generalized forms with red asymptomatic papules have also been reported [2]. Clinical differential diagnoses include granuloma annulare, actinic granuloma, atypical necrobiosis lipoidica, and granuloma multiforme. Although reticular variants of AEGCG have been described [6, 7], apityriasis versicolor-like clinical presentation in our case has never been reported in the literature. This unusual presentation should be considered as a rare manifestation of AEGCG.

The histological appearance of AEGCG is characteristic, with an image of giant cell elastophagic granuloma from which the name of the disease is taken. There is no mucin deposit or necrobiosis seen in granuloma annulare and necrobiosis lipoidica [8]. This appearance allows the disease to be differentiated from a number of other granulomatous diseases. The pathological findings in our patient are typical of AEGCG. Some authors consider AEGCG as a prodromal stage of Mid-Dermal Elastolysis (MDE) [9]. They suggest that AEGCG and MDE might represent different stages in the clinical spectrum of dermal elastolysis [9].

The etiology is unknown and treatment is empirical. Spontaneous remission can occur [7-10], and consistent results have not been obtained with any treatments [11]. Previously reported effective therapies for AEGCG include topical and intralesional steroid [12, 13], oral antimalarials, such as quinacrine [14], chloroquine [3], and hydroxychloroquine [1518], clofazimine [19], topical pimecrolimus [20], tarcrolimus, $[4,21]$ oral retinoid acid derivatives like isotretinoin [22] and acitretin [23-24], dapsone [25], fumaric acid [26], cyclosporine $[27,28]$, and minocycline [29]. Phototherapy (such as PUVA [30] or narrow band UVB [31]) is also effective in some cases. However, some patients show poor responses to these therapies. Our patient did not respond to topical steroids, nor did he receive any other treatment due to lost follow-up.

In conclusion, although the clinical findings of localized or generalized annular erythematous papules and plaques with atrophic center over sun-exposed area are the cardinal presentation of AEGCG, the pityriasis versicolor-like manifestation should also be considered as a rare clinical variant.

\section{References}

1. Hanke CW, Bailin PL, Roenigk HH Jr. Annular elastolytic giant cell granuloma: A clinicopathologic study of five cases and a review of similar entities. J Am Acad Dermatol. 1979;1(5):413-421.

2. Klemke CD, Siebold D, Dippel E. Generalised annular elastolytic giant cell granuloma. Dermatology. 2003;207(4):420-422.

3. Özkaya-Bayazıt E, Büyükbabani N, Baykal C, Oztürk A, Okçu M, Soyer HP. Annular elastolytic giant cell granuloma: sparing of a burn scar and successful treatment with chloroquine. Br J Dermatol. 1999;140:525530 .

4. Rongioletti F, Baldari M, Burlando M, Parodi A. Papular elastolytic giant cell granuloma: report of a case associated with monoclonal gammopathy and responsive to topical tacrolimus. Clin Exp Dermatol 2010;35(2):145-148.

5. Chou WT, Tsai TF, Hung CM, Ko WC. Multiple annular erythematous plaques on the back. Annular elastolytic giant cell granuloma (AEGCG). Indian J Dermatol Venereol Leprol . 2011;77(6):727-728. doi: 10.4103/0378-6323.86500.

6. Hinrichs R, Weiss T, Peschke E, Scharffetter-Kochanek K, Weber L. A reticular variant of elastolytic giant cell granuloma. Clin Exp Dermatol. 2006;31(1):42-44.

7. Misago N, Ohtsuka Y, Ishii K, Narisawa Y. Papular and reticular elastolytic giant cell granuloma: rapid spontaneous regression. Acta Derm Venereol . 2007;87(1);89-90.

8. Limas C. The spectrum of primary cutaneous elastolytic granulomas and their distinction from granuloma annulare: A clinicopathological analysis. Histopathology. 2004;44(3):277-282.

9. Müller FB, Groth W. Annular elastolytic giant cell granuloma: A prodromal stage of mid-dermal elastolysis? Br J Dermatol. 2007;156(6):1377-1379.

10. Hermes B, Haas N, Czarnetzki BM. Annular elastolytic giant cell granuloma with a spontaneous healing tendency. Hautarzt. 


$$
\text { 1995;46(7):490-493. }
$$

11. Gutiérrez-González E, Pereiro M Jr, Toribio J. Elastolytic Actinic Giant Cell Granuloma. Dermatol Clin. 2015;33(3):331-341. doi:10.1016/j. det.2015.03.002

12. Kato H, Uyeki Y, Yaoita H. Papular lesions associated with annular elastolytic giant cell granuloma. J Am Acad Dermatol. 1989;21(2 Pt 2):398-400.

13. Boneschi V, Brambilla L, Fossati S, Parini F, Alessi E. Annular elastolytic giant cell granuloma. Am J Dermatopathol. 1988;10(3):224-228.

14. Kelly BJ, Mrstik ME, Ramos-Caro FA, Iczkowski KA. Papular elastolytic giant cell granuloma responding to hydroxyl chloroquine and quinacrine. Int J Dermatol. 2004;43(12):964-966.

15. Babuna G, Buyukbabani N, Yazganoglu KD, Baykal C. Effective treatment with hydroxychloroquine in a case of annular elastolytic giant cell granuloma. Indian J Dermatol Venereol Leprol. 2011;77(1):110-111. doi: 10.4103/0378-6323.74988.

16. Can B, Kavala M, Türkoğlu Z, Zindancı I, Topaloğlu F, Zemheri E. Successful treatment of annular elastolytic giant cell granuloma with hydroxyl chloroquine. Int J Dermatol. 2013;52(4):509-511. doi: 10.1111/j.1365-4632.2011.04941.x

17. Goncalves RR, Miranda MF, VianaFde O, Cavaleiro LH, Fonseca DM. Annular elastolytic giant cell granuloma--case report. An Bras Dermatol. 2011;86(4 Suppl 1):S69-71.

18. Arora S, Malik A, Patil C, Balki A. Annular elastolytic giant cell granuloma: A report of 10 cases. Indian Dermatol Online J. 2015;6(Suppl 1):S17-20. doi: 10.4103/2229-5178.171055

19. Vehring KH, Bonsmann G, Brecker EB, Hamm H. Annular elastolytic giant cell granuloma-differential diagnosis of cutaneous granulomatosis. Hautarzt. 1991;42(6):391-395.

20. Errichetti E, Stinco G, Avellini C, Patrone P. Annular elastolytic giant cell granuloma treated with topical pimecrolimus. Indian J Dermatol Venereol Leprol. 2014;80:475-476. doi: 10.4103/03786323.140331.

21. Espiñeira-Carmona MJ, Arias-Santiago S, Aneiros-Fernández J, Fernández-Pugnaire MA, Naranjo-Sintes R, Aneiros-Cachaza J.
Annular erythematous papules in the neckline. Dermatol Online J. 2011;15;17(1):7.

22. Ratnavel RC, Grant JW, Handfield-Jones SE, Norris PG. O’Brien's actinic granuloma: Response to isotretinoin. J R Soc Med. 1995;88(9):528P-529P.

23. Coutinho ID, Ramos LI, Brites MM, Tellechea O. O’Brien Actinic Granuloma: A Case Report and Brief Review of Literature. Indian J Dermatol. 2015;60(4):391-393. doi: 10.4103/0019-5154.160493.

24. Stefanaki C, Panagiotopoulos A, Kostakis P, Stefanaki K, Petridis A. Actinic granuloma successfully treated with acitretin. Int J Dermatol. 2005;44(2):163-166.

25. Igawa K, Maruyama R, Katayama I, Nishioka K. Anti oxidative therapy with oral dapsone improved HCV antibody positive annular elastolytic giant cell granuloma. J Dermatol. 1997;24(5):328-331.

26. Gutzmer R, Breuer K, Kiehl P, Kiehl P, Kapp A, Werfel T. Successful therapy of annular elastolytic giant cell granuloma with fumaric acid esters. Dermatology. 2002;205(4):421-424.

27. Tsutsui K, Hirone T, Kubo K, Matsui Y. Annular elastolytic giant cell granuloma: response to cyclosporin A. J Dermatol. 1994;21(6):426429.

28. Ventura F, Vilarinho C, da Luz Duarte M, Pardal F, Brito C. Two cases of annular elastolytic giant cell granuloma: Different response to the treatment. Dermatol Online J. 2010;15;16(3):11.

29. Nanbu A, Sugiura K, Kono M, Muro Y, Akiyama M. Annular Elastolytic Giant Cell Granuloma Successfully Treated with Minocycline Hydrochloride. Acta Derm Venereol. 2015;95(6):756-757. doi: 10.2340/00015555-2056

30. Djilali-Bouzina F, Grange F, Krzisch S, Schnebelen MP, Grosshans E, Guillaume JC. Annular elastolytic giant cell granuloma. Ann Dermatol Venereol. 2010;137(8-9):536-540. doi: 10.1016/j. annder.2010.06.004

31. Takata T, Ikeda M, Kodama H, Ohkuma S. Regression of popular elastolytic giant cell granuloma using narrow-band UVB irradiation. Dermatology. 2006;212(1):77-79. 